\title{
Flood- and Drought-Related Natural Hazards Activities of the U.S. Geological Survey in New England
}

The U.S. Geological Survey (USGS) has many ongoing and recent water-related natural hazard activities in New England that can be used to help mitigate the effects of natural hazards in cooperation with other agencies. The themes related to potential hazards and the tools and science to better understand and address them include the following:

Erosion and landslides

- Fluvial erosion (sediment transport, bridge scour, and bankfull channel geometry characterization)

- Current and historic landslide mapping

Flood documentation and assessment

- Flood high-water marks

- Flood modeling and frequency analysis

- Flood inundation mapping

- Peak-flow regression equations

Drought documentation and assessment

- Drought frequency analysis

- Low-flow frequency and flow duration statistics

- Water use and availability during drought
Hydrologic monitoring

- Streamflow monitoring network

- Groundwater monitoring network

- Tidal monitoring network

- Snow surveys and ice jam monitoring

Tools for natural hazard assessment and mitigation

- Light detection and ranging (lidar) remote sensing technology

- StreamStats Web-based tool for streamflow statistics

- Flood inundation mapping

\section{Erosion and Landslides}

\section{Fluvial Erosion}

Fluvial geomorphic hazards, such as erosion and sediment transport, can damage infrastructure, such as buildings, bridges, dams, and roads, degrade aquatic habitats, compromise water supplies, and transport chemical constituents. Storm runoff can transport large quantities of suspended and bedload sediments. The transport happens through streambed and streambank scour, overland flow inputs to a river, and scour around structures.

\section{Sediment Transport}

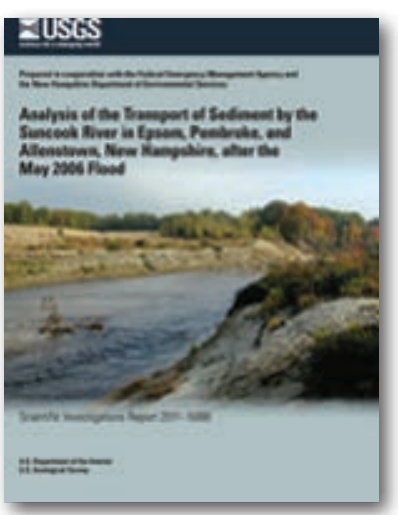

The USGS, the Federal Emergency Management Agency (FEMA), and the New Hampshire Department of Environmental Services studied sediment transport in the Suncook River in Epsom, New Hampshire, from a breach in the river's banks following a flood in 2006. Publication at http://pubs.er.usgs.gov/ publication/sir20115088.

\section{Bankfull Channel Geometry Characterization}

The USGS has developed regression equations for estimating bankfull width, mean depth, cross-sectional area, and discharge for streams in Massachusetts and Maine. Publications at http://pubs.er.usgs.gov/ publication/sir20045042 and

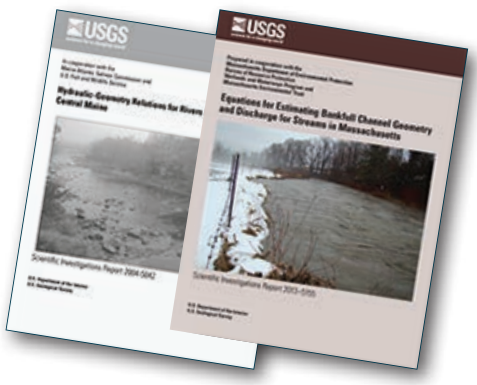
http://dx.doi.org/10.3133/sir20135155.

\section{Landslide Mapping}

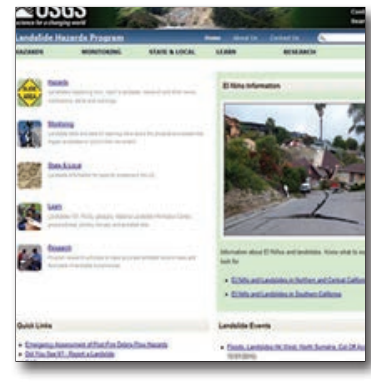

Landslides occur in all 50 States and annually cause $\$ 1$ to 2 billion in damages and more than 25 fatalities on average. Several landslides occurred in Massachusetts, New Hampshire, and Vermont as a result of Tropical Storm Irene on August 28, 2011. The USGS Landslides Hazards Program (http://landslides.usgs.gov/) strives to improve the understanding of landslide hazards to help protect communities and reduce associated and repetitive losses. The National Cooperative Geologic Mapping Program (http://ncgmp.usgs.gov/) is a critical asset in mapping historical landslides as well as recent occurrences. 


\section{Flood Documentation and Assessment}

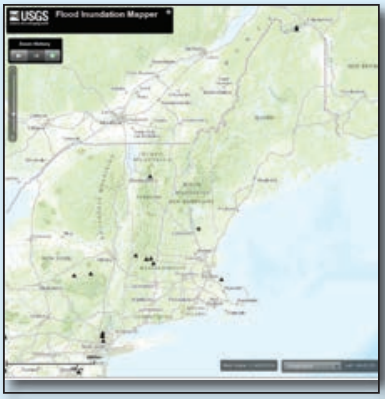

Flooding is New England's most frequent and costly natural disaster (U.S. Geological Survey, 1995). The USGS provides data and analyses for emergency preparedness, response, and mitigation. Following flood disaster declarations by FEMA, the USGS has documented flood elevations with high-water marks, modeled streamflows and recurrence intervals, created flood recovery maps to document the areal extent of flooding, and provided communities with information to aid in rebuilding. Following record rainfall totals in the Northeast from severe storms in 2005, 2006, and 2010 and Tropical Storm Irene in 2011, the USGS published flood recovery reports throughout New England.

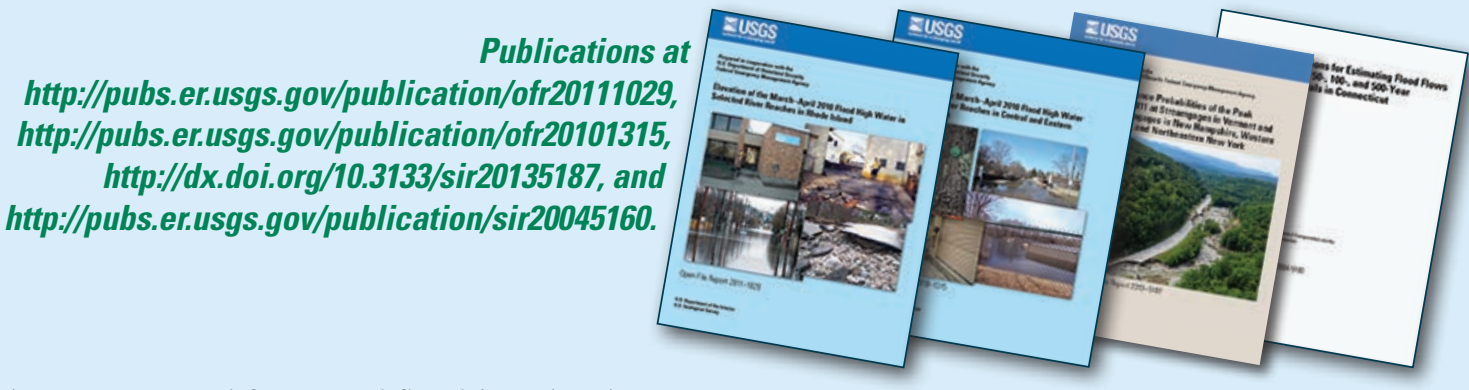

\section{Flood Inundation Mapper}

Flood-inundation maps show current and forecasted flood-inundated areas overlaid on high-resolution, georeferenced aerial photographs of an area. The maps provide emergency management personnel and communities with flood potential information that is critical for response activities, such as building evacuations, road closures, disaster declarations, and recovery efforts. Flood inundation maps (http://wimcloud.usgs.gov/apps/FIM/FloodlnundationMapper.html) can easily be created for any stream reach that has a National Weather Service (NWS) flood forecast streamgage, lidar, and a hydraulic model. Roughly 55 percent of all USGS streamgages nationwide are also NWS forecast gages (U.S. Geological Survey, 1995). Recent New England flood inundation work is listed below. The USGS cooperated with FEMA in 2015 to develop flood inundation maps for portions of the Hoosic, Deerfield, North, and Green Rivers in northwestern Massachusetts and the Winooski River in central Vermont.

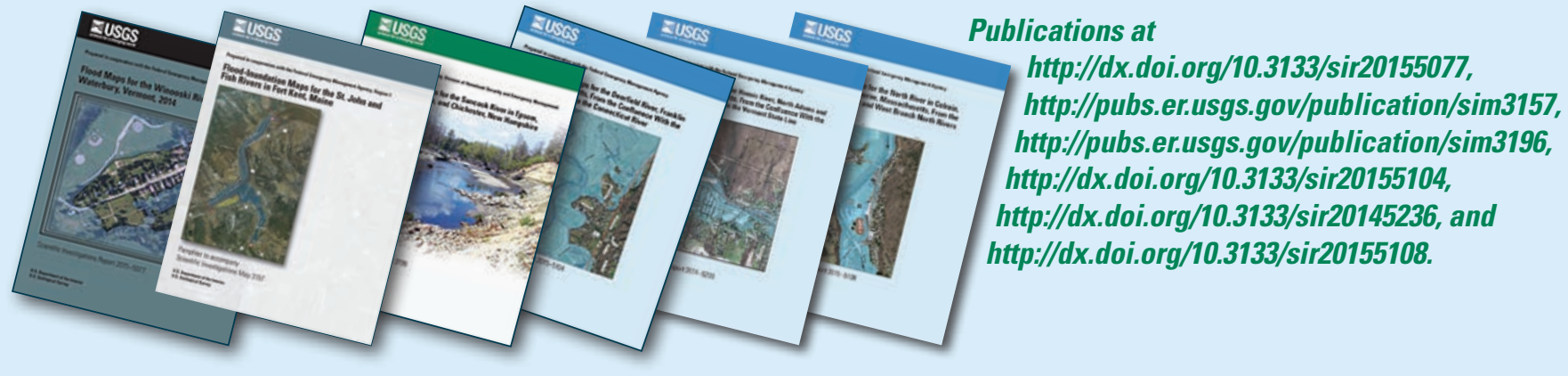

\section{Drought Documentation and Assessment}

Although floods are relatively short-term phenomena, droughts can persist for months and even years during precipitation deficits. In New England, droughts can cause private drinking-water wells to go dry, limit surface-water and groundwater withdrawals for municipal and commercial uses, affect aquatic habitat, and result in severe stream water-quality issues downstream of pollution sources.

The USGS analyzes data from streamgages and groundwater wells (http://waterdata.usgs.gov/nwis) to develop statistical summaries of low flow and groundwater levels during periods of drought. Real-time data and statistics are important for determining drought warnings by state agencies, planning and allocating water resources across New England, and managing and protecting fish and wildlife populations.
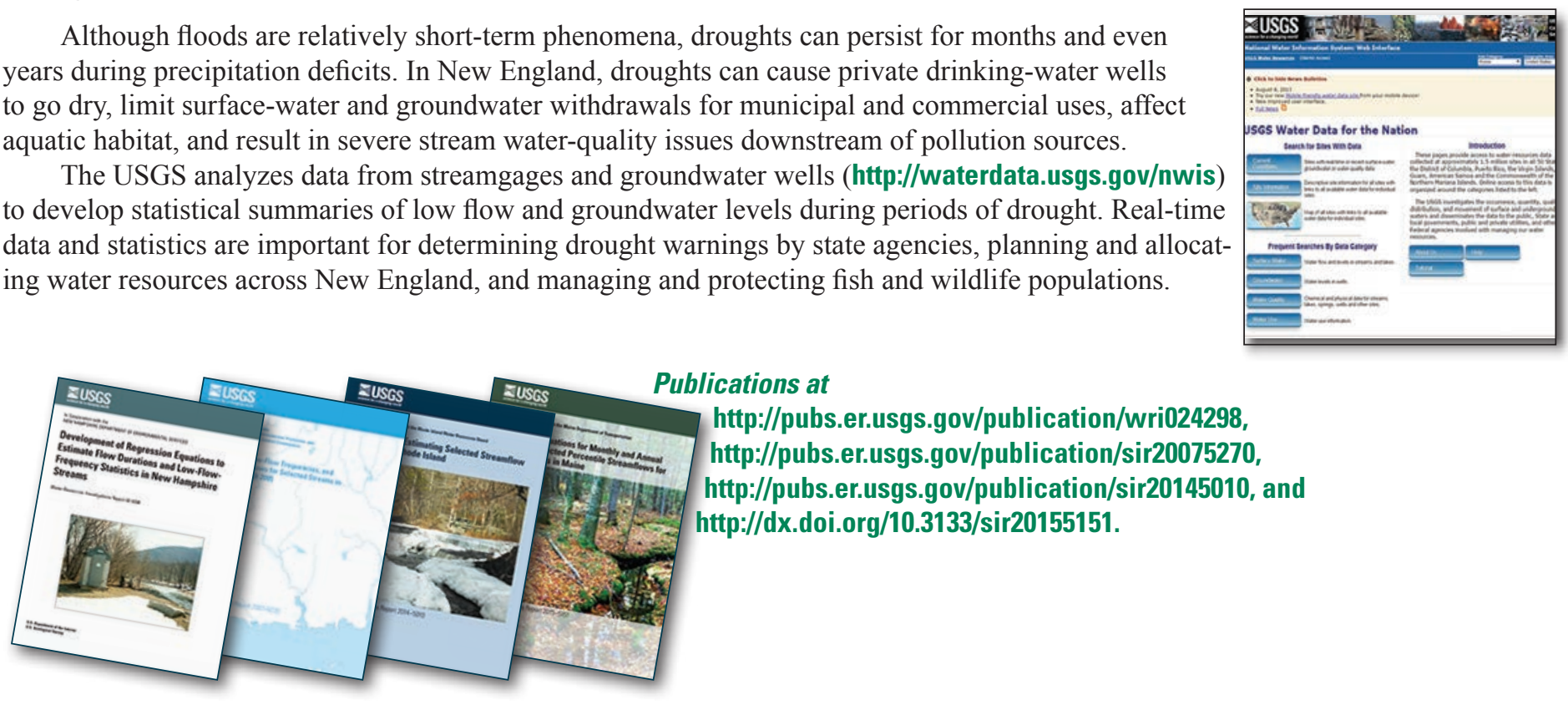


\section{Hydrologic Monitoring}

The USGS has cooperated for many years with multiple Federal and State agencies to establish, maintain, and expand streamflow, groundwater, and tidal monitoring networks throughout New England (http://newengland.water.usgs.gov/index.html) to assess and investigate floods and droughts.

\section{Streamflow Monitoring Network}

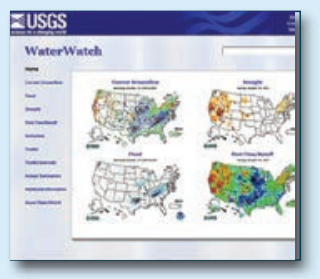

The USGS operates more than 400 streamgages in New England

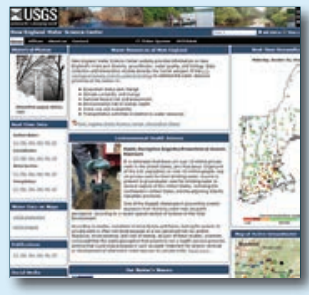
(http://waterwatch.usgs.gov/). Streamgage data are transmitted in real time through cellular telephone and satellite technology to the Internet to assist Federal and State emergency management agencies in monitoring flow levels and dams and flood control systems and in forecasting flood stages and timing.

\section{Groundwater Monitoring Network}

The USGS operates 57 groundwater monitoring wells in New England that collect data on an hourly basis and disseminate the data in near real time. The USGS also provides data from 180 groundwater wells in New England that are measured monthly. The groundwater monitoring data are available on the USGS New England Groundwater Network (http://groundwaterwatch.usgs.gov/netmapT2L1.asp?ncd=NEN).

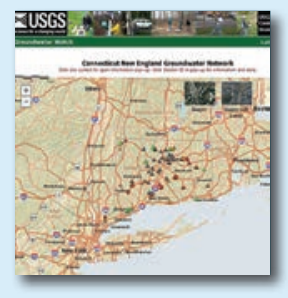

\section{Tidal Monitoring Network}

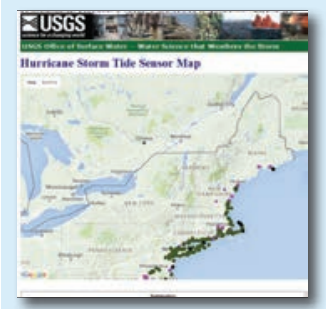

The USGS operates 10 permanent tidal gages to continuously monitor water levels in coastal New England. In addition, the USGS has installed 245 mounting stations for temporary storm surge sensors and 17 rapid-deployment gages along the coast of New England. Monitoring equipment is installed quickly at these stations in the hours and days prior to a storm. The Hurricane Storm Tide Sensor Map (http://waterwatch.usgs.gov/hsss/index.php) displays tide and flood data collected since 2005. In 2015, the USGS monitored and reported on the tidal surge associated with a major Nor'easter storm. Publication at http://dx.doi.org/10.3133/ofr20151081.

\section{Snow Surveys and Ice Jam Monitoring}

The USGS, in cooperation with other Federal, State, and local agencies and businesses, collects, interprets, and distributes snow depth and water content data in parts of New England during the late winter and early spring when the danger of riverine flooding is greatest due to snowmelt. Information such as that from the Maine cooperative snow survey (http://www.maine.gov/rfac/rfac_snow.shtml) is transmitted to the NWS for preparing flood potential statements and running flood forecast models.

The USGS works with Federal and local emergency management officials to monitor hazardous ice accumulation on rivers in northern New England. The USGS provides real-time river stage data and monitoring on the Internet through online live-broadcasting cameras of ice conditions

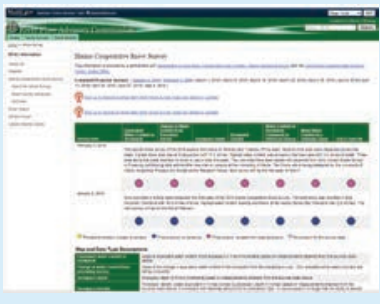
at vulnerable locations, such as the Kennebec River at Calumet Bridge at Augusta, Maine station (http://waterdata.usgs.gov/me/nwis/uv/?site_no=01049320). The U.S. Army Corps of Engineers and the NWS evaluate these locations for potential ice jam formation and river flooding.

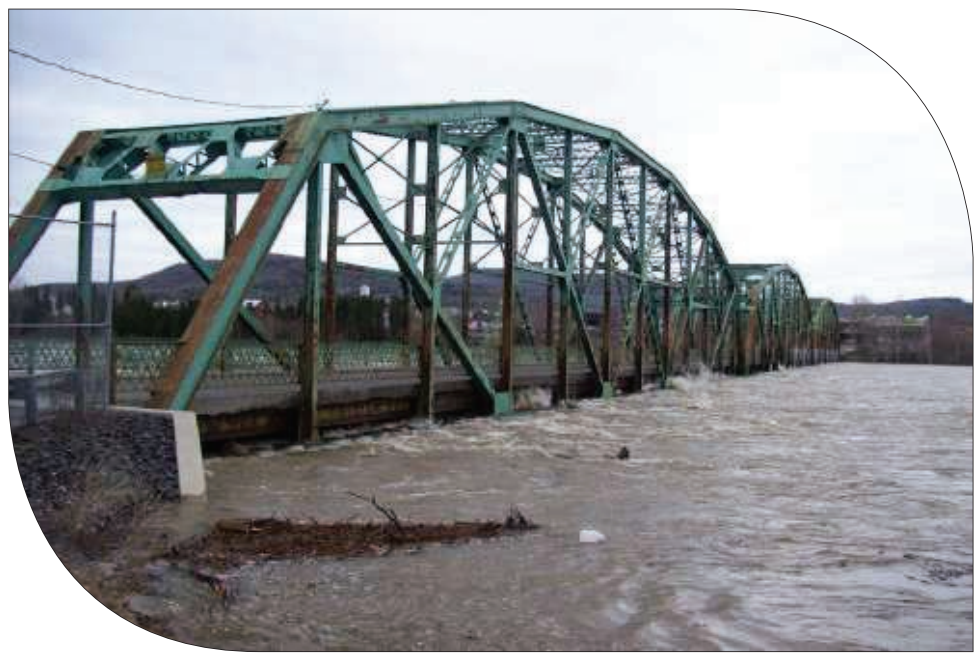

Flooded bridge on the St. John River in Maine. A major flood in 2008 was the highest flow measured at the U.S. Geological Survey St. John River at Fort Kent, Maine station (01014000), based on a record going back to the 1920s. Photograph by the U.S. Geological Survey. 


\section{Tools for Natural Hazard Assessment and Mitigation}

The USGS is at the forefront of technological advances and water resources tools to assess and mitigate natural hazards.

\section{Lidar}

Lidar is an essential remote sensing technology for applications that rely on highquality elevation data. The USGS and other scientific organizations researching hazards need accurate topographic and bathymetric information. The USGS has responded to the growing need for high-quality topographic data with the 3D Elevation Program (3DEP; http://nationalmap.gov/3DEP/), which provides elevation products that can be used to create 2- to 4-foot contour intervals. As a result of 3DEP, scientists and managers can access accurate elevation information through The National Map (http://viewer.nationalmap.gov/viewer/) and can plan projects to fly new lidaracquisition missions in cooperation with the USGS when existing data are not adequate.

\section{StreamStats}

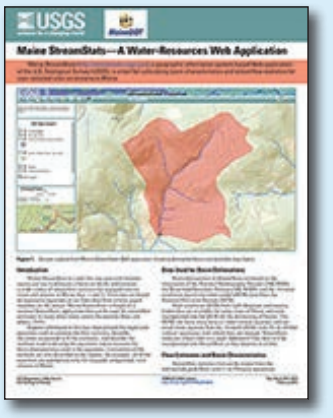

The USGS has worked with multiple agencies to develop equations for estimating streamflow statistics throughout New England. Users can estimate peak streamflow statistics with 2- to 500-year recurrence intervals, low-flow durations and frequencies, monthly and annual flows, probability of a stream flowing perennially, and bankfull discharge. StreamStats (http://water.usgs.gov/osw/streamstats/) is a tool that any user with Internet access can use to quickly delineate a basin and estimate streamflow statistics for ungaged sites on streams throughout New England.

\section{Flood Inundation Mapper}

All USGS flood inundation mapping projects are integrated in the Flood Inundation Mapper (http://wimcloud.usgs.gov/apps/FIM/FloodlnundationMapper.html). Users can zoom to a specific area of interest and print maps that will help them identify specific areas of flooding related to flood forecast streamgages.

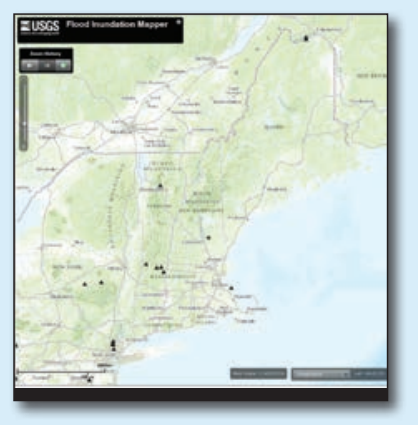

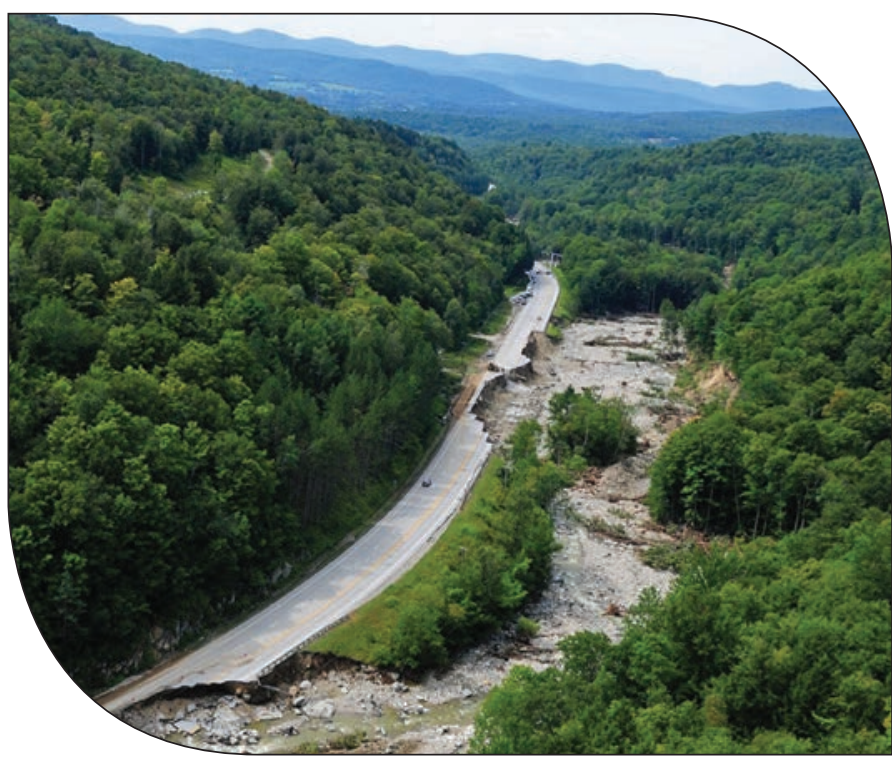

Aerial view of damage along U.S. Route 4 in Mendon, Vermont, as a result of floodwaters from Mendon Brook during Tropical Storm Irene in August 2011. Photograph by the U.S. Geological Survey.

\section{Reference Cited}

U.S. Geological Survey, 1995, Stream gaging and flood forecasting: U.S. Geological Survey Fact Sheet 95-209, 4 p., accessed at http://water.usgs.gov/wid/FS_209-95/mason-weiger.html.

\section{For more information, contact:}

Director, New England Water Science Center

U.S. Geological Survey

331 Commerce Way, Suite 2

Pembroke, NH 03275

Email: dc_nweng@usgs.gov

or visit our Web site at

http://newengland.water.usgs.gov/ 